\title{
M.M. SPERANSKY AND N.M. KARAMZIN: TWO WAYS OF CIVILIZED DEVELOPMENT OF RUSSIA OR A DISPUTE ABOUT A RATIONAL SYSTEM OF PUBLIC ADMINISTRATION?
}

\author{
Oleg V. Kuznetsov \\ Volgograd State University, Volgograd, Russian Federation \\ Konstantin A. Lotarev \\ Volgograd State University, Volgograd, Russian Federation \\ Vasiliy V. Tarakanov \\ Volgograd State University, Volgograd, Russian Federation
}

\begin{abstract}
Introduction. The introduction identifies one of the most important problems in the political history of Russia - the problem of determining and choosing the path of the long-term civilizational development in the aspect of liberal and conservative paradigm. Methods and materials. As the main methods the authors apply: the historical-comparative, systemic, typological and historical-political ones. The main sources are the following: "Plan of State Transformation" by M.M. Speransky and "Note on Ancient and New Russia in Its Political and Civil Relations" by N.M. Karamzin. Analysis. In the course of the comparative analysis the authors carry out the study of the plan of M.M. Speransky's state reforms and N.M. Karamzin's political program in the aspect of the liberal and conservative axiology. The authors conclude that there were two different models of civilizational development of the state. One of them, represented by M.M. Speransky, suggested radical changes in the political system, legislation, social relations and led Russia to the liberal Western path of development. N.M. Karamzin proceeded from the priority of national and state traditions and the perniciousness of transferring European political institutions, customs and practicies to the Russian soil. Results. The result of the study is the conclusion that in the complete absence of a basis for the formation of liberalism in Russia, M.M. Speransky's constitutional search was doomed to failure and resulted in the practice of building a system of the rational public administration within the framework of absolutism. Centuries-old historical traditions of Russia were much stronger than the desire of Alexander I to give the country a Constitution.

Key words: history of Russia of the $19^{\text {th }}$ century, autocracy, reform, political thought, liberalism, conservatism, traditionalism.

Citation. Kuznetsov O.V., Lotarev K.A., Tarakanov V.V. M.M. Speransky and N.M. Karamzin: Two Ways of Civilized Development of Russia or a Dispute About a Rational System of Public Administration? Vestnik Volgogradskogo gosudarstvennogo universiteta. Seriya 4. Istoriya. Regionovedenie. Mezhdunarodnye otnosheniya [Science Journal of Volgograd State University. History. Area Studies. International Relations], 2019,
\end{abstract}

М.М. СПЕРАНСКИЙ И Н.М. КАРАМЗИН: ДВА ПУТИ ЦИВИЛИЗАЦИОННОГО РАЗВИТИЯ РОССИИ ИЛИ СПОР О РАЦИОНАЛЬНОЙ СИСТЕМЕ ГОСУДАРСТВЕННОГО УПРАВЛЕНИЯ?

\section{Олег Викторович Кузнецов}

Волгоградский государственный университет, г. Волгоград, Российская Федерация 
Константин Анатольевич Лотарев

Волгоградский государственный университет, г. Волгоград, Российская Федерация

Василий Валерьевич Тараканов

Волгоградский государственный университет, г. Волгоград, Российская Федерация

\begin{abstract}
Аннотация. Во введении обозначена одна из важнейших проблем в политической истории России проблема определения и выбора пути долговременного цивилизационного развития в аспекте либеральной и консервативной парадигмы. В качестве основных методов авторами применяются: историко-сравнительный, системный, типологический и историко-политологический. В качестве основных источников привлекаются: «План государственного преобразования» М.М. Сперанского и «Записка о древней и новой России в ее политическом и гражданском отношениях» Н.М. Карамзина. В ходе сравнительного анализа авторами осуществлено исследование плана государственных преобразований М.М. Сперанского и политической программы Н.М. Карамзина в аспекте либеральной и консервативной аксиологии. Делается вывод о том, что были предложены две различные модели цивилизационного развития страны. Одна, представляемая M.M. Сперанским, предполагала радикальные изменения в политическом строе, законодательстве, социальных отношениях и выводила Россию на либеральный западный путь развития. Н.М. Карамзин исходил из приоритета национально-государственных традиций и пагубности перенесения на российскую почву европейских политических институтов, нравов и обычаев. Результатом исследования является вывод о том, что при полном отсутствии базы для формирования либерализма в России конституционные поиски М.М. Сперанского были обречены на провал и вылились на практике в выстраивание системы рационального государственного управления в рамках абсолютизма. Вековые исторические традиции России оказались гораздо сильнее стремления Александра I дать стране конституцию. О.В. Кузнецов проанализировал «Записку о древней и новой России...» Н.М. Карамзина, К.А. Лотарев проанализировал «План государственного преобразования» М.М. Сперанского. В.В. Тараканов сформулировал концепцию статьи, подготовил разделы «Введение», «Методы и материалы», «Результаты».
\end{abstract}

Ключевые слова: история России ХІХ в., самодержавие, реформы, общественно-политическая мысль, либерализм, консерватизм, традиционализм.

Цитирование. Кузнецов О. В., Лотарев К. А., Тараканов В. В. М.М. Сперанский и Н.М. Карамзин: два пути цивилизационного развития России или спор о рациональной системе государственного управления? // Вестник Волгоградского государственного университета. Серия 4, История. Регионоведение. Международные отношения. - 2019. - Т. 24, № 5. - C. 86-99. - DOI: https://doi.org/10.15688/jvolsu4.2019.5.6

Введение. В начале XXI века, как и два столетия назад, Россия оказалась на своеобразном цивилизационном распутье. Столь ожидаемые обществом либеральные реформы 1990-х гг. навсегда, казалось, определили западную модель дальнейшего развития страны. Но, обманув многие ожидания, реформы стали ассоциироваться с неизбежным распадом государства, экономической деградацией и финансовой зависимостью от Запада, тотальной коррупцией и казнокрадством, разрушением традиционных духовно-нравственных ценностей и т. п. Либеральные идеи очень быстро утратили свою популярность. Слово «либерал» начинает восприниматься как ругательное, а либеральную идеологию заметно потеснила консервативная. Все это, в сочетании с отказом Запада признавать Россию полноправной европейской страной, заставило говорить о необходимости возвра- щения к национально-государственным ценностям и традициям. Вместе с тем либеральные преобразования 1990-х гг. уже пустили достаточно глубокие корни и сделали едва ли возможным возращение на социалистический путь развития. Причудливое соединение элементов консерватизма, либерализма и социализма в нашей современной жизни оставляет отрытым вопрос о модели дальнейшего развития страны.

Методы и материалы. Авторы статьи обращаются к одному из переломных периодов политической истории нашей страны с точки зрения столкновения либерального и консервативного (то есть основанного на вековых исторических традициях страны) подходов - началу царствования Александра I.

В настоящей статье авторы применяют системный метод исследования, позволяющий анализировать процессные явления не изоли- 


\section{ВЛАСТЬ И ОБЩЕСТВО}

рованно друг от друга, но в тесной взаимосвязи и взаимовлиянии. Историко-сравнительный и типологический методы дают возможности сопоставления идей в аспекте возможного, приемлемого и рационально обоснованного пути в поиске наиболее приемлемой модели или системы государственного управления. Историко-политологический анализ дает возможность актуализировать данную проблематику в условиях современного политического процесса в России и поиска приемлемой и стабильной системы в государственном управлении.

В качестве основных источников привлекаются: «Записка о древней и новой России в ее политическом и гражданском отношениях» H.M. Карамзина и «План государственного преобразования» М.М. Сперанского.

Анализ. Правительственный конституционализм Александра I в первые годы его царствования, нашедший выражение не столько в действиях, сколько в намерениях императора и в политических проектах М.М. Сперанского, встретил сопротивление со стороны широких слоев дворянства. Выразителем его недовольства стал историк Н.М. Карамзин. Мы попытаемся предложить свое понимание проблемы, вынесенной в название статьи: можно ли говорить в отношении М.М. Сперанского и Н.М. Карамзина о двух различных моделях - либеральной и консервативной (традиционной) - дальнейшего развития страны или спор шел лишь о рационализации системы государственного управления в рамках существующего строя, позволявшей самодержавию адаптироваться к новым историческим условиям. И насколько предопределена была неудача реформ начала царствования Александра I?

В представлении современников Александра I планы радикальных преобразований системы государственного управления в первые годы его царствования и частичная их реализация справедливо связаны с именем М.М. Сперанского. В чем, собственно, главные идеи М.М. Сперанского, какое будущее России рисовалось в его политических проектах?

М.M. Сперанский исходил из идеи единства закономерности исторического процесса. И с этой точки зрения европейская история, в том числе и российская, подчиняясь определенным закономерностям («борьба системы республик с системою феодальною»), проходит три стадии: система феодальных уделов, система феодального самодержавия, система республик. Главным содержанием и конечным результатом борьбы сменяющих друг друга систем является утверждение политических и гражданских свобод. В Европе толчок переходу от «первой феодальной системы» ко второй был дан в период крестовых походов. В России подобный переход произошел благодаря «походам татарским», ослабившим могущество удельных князей.

В ряде европейских стран, по мере развития промышленности и просвещения, уже «основался третий период политического состояния государств». Россия пока пребывает на втором этапе. Переход к третьему может и должен произойти только в свое, исторически определенное время. Мысль о своевременности любых политических преобразований одна из важнейших в теоретических построениях М.М. Сперанского. Искусственное сдерживание назревших преобразований чревато социальными потрясениями. Попытки преждевременных реформ не только не приводят к желанному результату, но способны задержать движение к политической и гражданской свободе. Такие примеры М.М. Сперанский видел в русской истории.

Необходимость ограничения самодержавия «почувствована была» еще при Алексее Михайловиче. Первый серьезный, но неудачный шаг в этом направлении был сделан в 1730 г., когда «при восшествии императрицы Анны на престол Сенат мог и дерзнул пожелать политического существования и поставил себя между народом и престолом» [13, c. 21]. В этих событиях М.М. Сперанский увидел «первое доказательство» того, сколь тщетно стремиться опередить естественный ход вещей. Новую попытку дать России «бытие политическое» предприняла Екатерина II созывом Уложенной комиссии. И здесь M.M. Сперанский увидел стремление опередить время: «...громада сия (Уложенная комиссия. - O. K., K. Л., В. T.), усилием одного духа, без содействия времени составленная, от собственной своей тяжести пала, оставив по себе одну долголетнюю и горестную уко- 
ризну всем подобным сему предприятиям» $[13$, c. 23]. Неудача охладила желание Екатерины II проводить политические преобразования. А ее «Жалованные грамоты» остались всего лишь «опытами великого здания».

В то же время, полагал М.М. Сперанский, предшествующие полтора века не прошли даром: были заложены предпосылки серьезных политических реформ, и современная ему Россия, «без сомнения, имеет прямое направление к свободе». Пришло время перехода к третьему периоду: «...настоящая система правления несвойственна уже более состоянию общественного духа и... настало время переменить ее и основать новый вещей порядок» $[13$, с. 30]. Правда, оговаривался реформатор, переход к политическим и гражданским свободам мог занять длительное время. Эти либеральные в своей основе теоретические размышления М.М. Сперанского предваряли практическую часть его проекта.

Свой проект реформы государственного преобразования М.М. Сперанский прямо называл конституцией. Ее главное отличие от конституций других стран он видел в том, что последние появились в основном вследствие революционных потрясений. В отличие от них русская конституция будет добровольно дарована верховной властью, заботящейся единственно о благе подданных. Уже одно это обстоятельство являлось важнейшим ограничением планируемых преобразований, гарантией, что они не будут носить разрушительно радикального характера. Фактически М.М. Сперанский обосновывал необходимость не столько конституционного ограничения верховной власти, сколько ее четкого законодательного оформления. Это проект рационального устройства системы государственного управления в рамках абсолютной монархии, в которой самодержавию будет принадлежать вся полнота законодательной, исполнительной и судебной власти. «Все сии установления (законодательство, управление, суд. - О. К., К. Л., В. T.) соединяются в державной власти, яко в первом и верховном их начале» $[13$, с. 13].

Проект М.М. Сперанского неоднократно анализировался в исторической литератуpe (см., например: $[11 ; 18])$, поэтому, не останавливаясь на нем подробно, напомним главное. В соответствии с теорией разделения вла- стей М.М. Сперанский предлагал распределить все государственные дела на три группы - законодательство, управление, суд - и для каждой создать свою систему учреждений, от высших до местных. Ключевую роль в этой «триаде» играла законодательная вертикаль. Именно здесь подразумевалась теоретическая возможность ограничения верховной власти: «никакой закон не может иметь силы, если не будет он составлен в законодательном сословии» (то есть в Государственной думе) $[13$, с. 48]. Объединять работу трех «ветвей власти» должен был Государственный совет, «в коем все действия порядка законодательного, судного и исполнительного в главных их отношениях соединяются и через него восходят к державной власти и от нее изливаются» [13, с. 112]. Таким образом, верховной власти и Государственному совету принадлежало последнее и решающее слово во всех делах: «Никакой закон, устав и учреждение не исходит из совета и не может иметь своего совершения без утверждения державной власти» [13, с. 113].

На тот момент проект М.М. Сперанского не предусматривал сколько-нибудь серьезного ограничения самодержавной власти. Только с течением времени могла произойти, в случае полной реализации этого проекта и дополнительных законодательных усилий, подлинная эволюция от абсолютной монархии к конституционной.

Теоретически M.M. Сперанский не видел непреодолимых препятствий для решения крестьянского вопроса, точнее, для отмены крепостного права: «Нет никакого основания предполагать, чтобы в России не могло оно (рабство. - О. К., К. Л., В. Т.) уничтожиться, если приняты будут к тому действительные меры. Но чтобы меры сии были действительны, они должны быть постепенны» [13, с. 54]. Но это была лишь постановка проблемы, а не путь к ее решению.

В целом же в сословном вопросе М.М. Сперанский выглядит стоящим ближе к консерваторам, нежели к либералам, полагая, что права и свободы не могут быть распространены на все слои населения. Так, гражданские права он делил на личные и имущественные. И если первыми могли обладать представители всех сословий, то вторыми - только избран- 


\section{ВЛАСТЬ И ОБЩЕСТВО}

ные. Наличие имущественных прав определяло и участие в политической жизни: «...в составлении выборов никто не может участвовать, кто не имеет недвижимой собственности или капиталов промышленности в известном количестве» [13, с. 62]. Правда, М.М. Сперанский допускал возможность наделения всеми правами лиц низших сословий в случае приобретения ими недвижимого имущества [13, с. 67].

Проект М.М Сперанского внешне выглядит достаточно умеренно, если не сказать консервативно. Автор осознавал неизбежность, и даже необходимость, ограничения самодержавия и решения крестьянского вопроса, однако в его проекте по существу не предлагается ни то, ни другое.

Еще более скромными оказались практически результаты. Отметим некоторые из них.

Учрежденный Александром I в 1810 г. и предусмотренный в проектах М.M. Сперанского Государственный совет являлся прежде всего высшим законосовещательным органом во главе с императором и никоим образом не ограничивал верховную самодержавную власть. «Общее учреждение министерств» 1811 г., инициатором которого был М.М. Сперанский, знаменовало переходный период от коллегий к министерствам и предусматривало регламентацию деятельности центральных органов власти, также ни в чем не посягая на прерогативы монарха. На первый взгляд, указ «О правилах производства в чины по гражданской службе...» 1809 г., также инициированный М.М. Сперанским, имел либеральный характер, так как предусматривал по сути буржуазный принцип чинопроизводства: повышение в должности в зависимости от образования. Но здесь прежде всего бросается в глаза весьма ограниченный характер этого закона. Он касался только чиновников, претендующих на должности, соответствовавшие пятому и восьмому классам Табели о рангах. Этот указ больше наделал шума, нежели принес практическую пользу: уже через несколько лет о нем благополучно забыли. Таким образом, в практической деятельности М.М. Сперанского на первый план выступают не либеральные преобразования, а стремление бюрократа «до мозга костей» (каковым, на наш взгляд, он и являлся; один из современных биографов М.М. Сперанского, В.А. Томсинов, очень точно назвал книгу о нем - «Светило российской бюрократии» [17]) рационализировать работу как отдельных государственных учреждений, так и государственного аппарата империи в целом.

Тем не менее, несмотря на очевидную умеренность проектов М.М. Сперанского, их внешне почти консервативный характер и еще большую умеренность практических результатов реформаторских замыслов Александpa I, ими определялась либеральная модель будущего развития страны. Эта модель предполагала продолжение политики европеизации, распространение ее на новые сферы, прежде почти не затронутые: формы государственных учреждений, законодательство, социальные отношения. Показательно в этом контексте теоретизирование М.М. Сперанского относительно соотношения политических и гражданских прав. «Хотя права гражданские и могут существовать без прав политических, но бытие их в сем положении не может быть твердо. <..> Истинные права гражданские должны быть основаны на правах политических, точно так же, как и закон гражданский вообще не может быть тверд без закона политического» $[13$, с. $7-8]$. Как видим, М.М. Сперанский считал принципиально важным, чтобы права (читай: свободы) политические предшествовали правам гражданским. Первые надежная гарантия вторых. Поясним, почему мы акцентируем на этом внимание.

Для утверждения полноценного либерализма принципиальное, на наш взгляд, значение имеет проблема соотношения гражданских и политических свобод. Что должно быть поставлено во главу угла: раскрепощение сословий или «начинать надо с трона... лестницу метут сверху», как остроумно заметил по этому поводу известный русский либерал Н.С. Мордвинов?

Современные исследователи В.В. Ведерников и В.А. Китаев обратили внимание на уязвимость позиции автора фундаментальной монографии по истории русского либерализма В.В. Леонтовича в вопросе о соотношении политических и гражданских свобод. Для него утверждение либерализма в России начинается с закрепления права частной собственности и гражданской свободы. Что касается политической свободы, то она лишь 
дополняет свободу гражданскую. При этом В.В. Леонтович не различает аристократическую и демократическую свободы, полагая их одинаково либеральными. Поэтому генезис либерализма В.В. Леонтович начинает с Екатерины II, признавшей право собственности дворян на землю и даровавшей дворянскому сословию гражданские свободы. Однако права и свободы дворянства, действительно являясь либеральными по своей сути, допускали двоякий результат: либеральную и одновременно консервативную оппозицию абсолютизму $[2$, с. $38,40-41$; для сравнения см.: 8 , с. $27-$ 51]. Продолжим эти размышления.

«Закрепощенное» в свое время Петром I и окончательно «раскрепощенное» Екатериной II дворянство стало подлинно господствующим сословием, а Россия превратилась в дворянскую империю. Консервативная часть дворянства бдительно стояла на страже своих сословных прав и привилегий, к числу которых она, безусловно, относила и право на владение крепостными крестьянами. И очень болезненно воспринимала любые попытки как ограничить хоть одно из этих прав, так и распространить их на другие сословия. Вспомним: попытка Павла I подвергнуть ревизии некоторые положения «Жалованной грамоты дворянству» привела к дворянскому заговору против императора и его убийству. Именно эта, консервативная, а отнюдь не либеральная, дворянская оппозиция будет препятствовать любым хоть сколько-нибудь значимым реформам на протяжении всего XIX века, включая и время царствования Александра I и проекты М.М. Сперанского.

Позиции В.В. Леонтовича относительно проблемы соотношения политических и гражданских свобод В.В. Ведерников и В.А. Китаев противопоставляют мнение одного из видных теоретиков и практиков русского либерализма - П.Б. Струве: «Историческое несчастье России, к которому восходит трагическая катастрофа 1917 г., обусловлено... тем, что политическая реформа страшно запоздала в России. В интересах здорового национально-культурного развития России она должна была бы произойти не позже начала XIX века. Тогда задержанное освобождение крестьян (личное) быстро за ней последовало бы, и все развитие политических и соци- альных отношений протекало бы нормальнее» [2, с. 42; см. также: 16, с. 241]. С закрепления политических свобод предлагал начинать, в частности, В.Н. Татищев, автор одного из проектов ограничения самодержавия во время заговора «верховников» в 1730 г., которого иногда называют «первым теоретиком русского либерализма» [2, с. 42; см. также: 4, с. 63]. Очевидно, что и М.М. Сперанский ставил отмену крепостного права в России в зависимость от успешного политического реформирования России.

Либеральный, по своей сути и конечному результату, характер модели М.М. Сперанского проявился также и в стремлении к предельной законодательной регламентации всех предлагаемых им институциональных форм. Либеральная, сама по себе, идея примата закона над традицией начала реализовываться в России в начале XVIII в., в ходе петровских реформ, ставших попыткой перехода от общества традиционного к обществу, основанному на рациональных началах. Тем самым фактически закладывались основы российского либерализма. Один из основоположников русского консерватизма, М.М. Щербатов, ставил Петру I в вину то, что именно с него начинается «повреждение нравов в России»: царьреформатор привил дворянству «сластолюбие», являвшееся не чем иным, как достаточно развитой формой утилитаризма. Последний же, с его осознанием связи роста благ и личных усилий по их добыванию, готовит почву для либерализма, выступает как его предшественник [5, с. 132]. Быть может, отнюдь не случайно с идеей ограничения верховной власти из «гнезда Петрова» «выпорхнул» В.Н. Татищев, упоминавшийся выше.

Наконец, буржуазным являлся принцип разделения властей, который взял за основу для своих проектов М.М. Сперанский.

Таким образом, предлагаемые Александром I и М.М. Сперанским европейские, по своему содержанию и существу, формы политической организации общества, законодательство, социальные отношения, соединенные с европейскими же обычаями, нравами, традициями, заимствование которых началось в предшествующие периоды, уверенно выводили Россию на буржуазный, западный путь развития. 


\section{ВЛАСТЬ И ОБЩЕСТВО}

Эту буржуазную, западную модель развития России и не мог принять Н.М. Карамзин. Его реакцией на попытку внедрения основ такой модели и стала «Записка о древней и новой России в ее политическом и гражданском отношениях». Не останавливаясь на деталях содержания «Записки», выделим здесь самое главное, касающееся полемики ее автора с Александром I и М.М. Сперанским.

Н.М. Карамзин не был ни сторонником изоляции России от европейских стран, ни противником заимствований достижений западной цивилизации, но призывал подходить к этому крайне осторожно и избирательно. Просвещение, по Н.М. Карамзину, состоит «в знании нужного для благоденствия: художества, искусства, науки не имеют иной цены» [3, с. 33]. Поэтому одно государство может заимствовать от другого «полезные сведения», не следуя этому, последнему, в обычаях. Именно такой характер носило сближение России с Европой в XVII в., при первых Романовых, когда «мы заимствовали, но как бы н е х о т я, применяя все к нашему и новое соединяя со старым» [3, с. 31].

Положение радикально изменилось, когда к власти пришел Петр I, поставивший целью «не только новое величие России, но и совершенное присвоение обычаев европейских» [3, с. 31]. Страсть к новому и чужому, по словам Н.М. Карамзина, «преступила в нем границы благоразумия» [3, с. 32]. В погоне за европейскими нравами и обычаями царь-реформатор стремился искоренить «дух народный», столь необходимый для нравственного могущества госуарства. В итоге россияне начали утрачивать одно из важнейших качеств, которое так ценил Н.М. Карамзин как историк и гражданин: патриотизм («гражданскую добродетель»). «Теперь же, более ста лет находясь в школе иноземцев, без дерзости можем ли похвалиться своим гражданским достоинством? <...> Мы стали гражданами мира, но перестали быть, в некоторых случаях, гражданами России. Виною Петр» [3, с. 34 35]. Собственно, в дальнейшем, «как при Анне, так и при Елизавете Россия текла путем, предписанным ей рукою Петра, более и более удаляясь от своих древних нравов и сообразуясь с европейскими» [3, с. 40]. Исключением в этом отношении не стало и царствование Ека- терины II: «чужеземцы овладели у нас воспитанием, двор забыл язык русский» [3, с. 43].

Такое же подражание Европе, только более опасное, затрагивающее сферу государственного управления, законодательство, социальные отношения, Н.М. Карамзин увидел и в начинаниях Александра I и в планах M.M. Сперанского: «Если история справедливо осуждает Петра I за излишнюю страсть его к подражанию иноземным державам, то оно в наше время не будет ли еще страшнее?» $[3$, c. 63].

В принципе «разделения властей», заимствованном из европейских политических учений и положенном в основу проекта административной реформы, Н.М. Карамзин справедливо разглядел возможность ограничения верховной власти. Это противоречило его политическим воззрениям и исторической концепции, восходящей к историографической традиции XVIII века. Изначально на Руси существовала монархия в форме сильной княжеской власти. Ее ослабление привело к распаду Руси и утверждению раздробленности. Восстановление единства государства было связано с возрождением сильной великокняжеской власти (монархии). Вся русская история доказывала неопровержимую для Н.М. Карамзина истину, что самодержавие - единственно возможная форма правления: «Россия основалась победами и единоначалием, гибла от разновластия, а спаслась мудрым самодержавием»; «Самодержавие основало и воскресило Россию: с переменою Государственного Устава ее она гибла и должна погибнуть, составленная из частей столь многих и разных, из коих всякая имеет свои особенные гражданские пользы. Что, кроме единовластия неограниченного, может в сей махине производить единство действия?» [3, с. 22, 48]. Неслучайно идея незыблемости самодержавия сквозная и одна из ключевых в «Записке». Для ее автора «самодержавие есть палладиум России» [3, с. 105].

Под «единовластием неограниченным», Н.М. Карамзин подразумевал неделимость самодержавной власти: монарх ни с кем не может и не должен делить свою власть. «Две власти государственные в одной державе суть два грозные льва в одной клетке, готовые тер- 
зать друг друга, а право без власти есть ничто» $[3$, с. 48$]$.

В то же время автор «Записки» настаивал на необходимости неконституционных ограничений монархии. К числу таковых он относил три ограничения. Во-первых, монарх не должен быть тираном, деспотом, как, к примеру, Иван IV или Павел I, который «к неизъяснимому изумлению россиян... начал господствовать всеобщи ужасом, не следуя никаким Уставам, кроме своей прихоти» [3, с. 45]. Самодержец должен быть сильным и при этом просвещенным, мудрым, человеколюбивым. Неслучайно Н.М. Карамзин отмечал, говоря о Екатерине II: «Главное дело сей незабвенной монархини состоит в том, что ею смягчилось самодержавие, не утратив силы своей» [3, с. 40]. Во-вторых, монарх не имеет права покушаться, как это делал Петр I, на народные обычаи и традиции. Они могут и должны изменяться естественным образом, без вторжения государства: «Народ в первоначальном завете с венценосцами сказал им: “Блюдите нашу безопасность вне и внутри, наказывайте злодеев, жертвуйте частью для спасения целого", - но не сказал: "противуборствуйте нашим невинным склонностям и вкусам в домашней жизни”» [3, с. 33]. Наконец, в-третьих, верховная светская власть не имеет права вторгаться в сферу действия власти церковной, имеющий свой «особенный круг действия». В противном случае церковь утратит свой священный характер, вера в нее ослабнет, в результате чего монарх лишится «способа владеть сердцами народа в случаях чрезвычайных, где нужно все забыть, все оставить для отечества, и где Пастырь душ может обещать в награду один венец мученический» [3, с. 36].

Кроме названного, монарх, по убеждению Н.М. Карамзина, не имел права еще на одно деяние: ограничивать собственную власть конституцией: «Если бы Александр, вдохновенный великодушною ненавистью к злоупотреблениям самодержавия, взял перо для предписания себе иных законов, кроме Божиих и совести, то истинный добродетельный гражданин российский дерзнул бы остановить его руку и сказать: “Государь! Ты преступаешь границы своей власти: наученная долговременными бедствиями, Россия пред святым алтарем вручила самодержавие твоему предку и требовала, да управляет ею верховно, нераздельно. Сей завет есть основание твоей власти, иной не имеешь; можешь все, но не можешь законно ограничить еe!..”” [3, с. 48]. Внешним, формальным ограничениям самодержавия Н.М. Карамзин противопоставлял ограничения, проистекающие из самой природы складывавшейся веками монархической власти, понимания ее содержания и предназначения.

К числу опасных заимствований Н.М. Карамзин относил и проект нового Уложения, разглядев в нем лишь перевод кодекса Наполеона. «Какое изумление для россиян! Какая пища для злословия! Благодаря Всевышнего, мы еще не подпали железному скипетру сего завоевателя, - у нас еще не Вестфалия, не Итальянское королевство, не Варшавское герцогство, где Кодекс Наполеонов, со слезами переведенный, служит Уставом гражданским. Для того ли существует Россия, как сильное государство, около тысячи лет? Для того ли около ста лет трудимся над сочинением своего полного Уложения, чтобы торжественно пред лицом Европы признаться глупцами и подсунуть седую нашу голову под книжку, слепленную в Париже 6-ю или 7[-ю] экс-адвокатами и экс-якобинцами?» - недоумевал по этому поводу Н.М. Карамзин [3, с. 90]. Его отношение к законодательству и законам требует отдельного разговора.

С одной стороны, необходимость законов автор «Записки» не отрицал, но считал, что в этом вопросе необходимо следовать определенным правилам и ограничиваться минимумом законотворческой деятельности. Законы должны быть не заимствованными, но отражать дух страны и народа, для которого они пишутся. По мнению Н.М. Карамзина, современные ему законодатели в деле заимствования превзошли самого Петра I: «Петр Великий любил иностранное, однако же не велел без всяких дальних околичностей, взять напр[имер], шведские законы и назвать их русскими, ибо ведал, что законы народа должны быть извлечены из его собственных понятий, нравов, обыкновений, местных обстоятельств» [3, с. 90-91]. При этом Н.М. Карамзин сомневался в необходимости и пользе новых законов. Он считал вполне достаточным 


\section{ВЛАСТЬ И ОБЩЕСТВО}

оставленного предшественниками Александpa I законодательного наследия. Следовало лишь систематизировать, частично дополнить и исправить «указы и постановления, изданные от времен царя Алексея до наших дней» [3, с. 93].

С другой стороны, в отношении законодательства Н.М. Карамзин придерживался идеи примата традиции над законом, особенно когда речь заходила о необходимости вписать в законодательные рамки верховную власть (выше мы уже отчасти коснулись этого сюжета) или даже поставить «закон еще выше государя», что фактически было равнозначно конституции. Россия, по Н.М. Карамзину, в ней не нуждалась. Слово самодержца и собственный его пример лучше любой конституции. «В России государь есть живой закон: добрых милует, злых казнит... ...наше правление есть отеческое, патриархальное. Отец семейства судит и наказывает без протокола, - так и монарх в иных случаях должен необходимо действовать по единой совести» [3, с. 102]. Самовластный российский монарх не обязан сверять каждый свой шаг с буквой закона или действовать с оглядкой на какие-либо учреждения, ибо он «внемлет только мудрости, где находит ее: в собственном ли уме, в книгах ли, в голове ли лучших своих подданных; но в самодержавии не надобно никакого одобрения для законов, кроме подписи государя; он имеет всю власть» [3, с. 60]. Удержать своих преемников от злоупотребления властью просвещенный монарх может не конституцией, но лишь примером личной добродетели: «...наш государь имеет только один верный способ обуздать своих наследников в злоупотреблениях власти: да царствует добродетельно! да приучит подданных ко благу!.. Тогда родятся обычаи спасительные; правила, мысли народные, которые лучше всех бренных форм удержат будущих государей в пределах законной власти... Чем? страхом возбудить всеобщую ненависть в случае противной системы царствования. Тиран может иногда безопасно господствовать после тирана, но после государя мудрого - никогда!» [3, с. 49].

В контексте идеи примата традиции над законом следует, видимо, рассматривать и неприятие Н.М. Карамзиным указа «О пра- вилах производства в чины по гражданской службе...», о котором упоминалось ранее. И здесь для Н.М. Карамзина, в отличие от М.М. Сперанского, «40-летняя деятельность государственная», «важные заслуги» (читай: традиция) автоматически освобождали опытного чиновника «от долга знать вещи, совсем для нас чуждые и бесполезные» (то есть от закона, требующего сдавать экзамен на чин). Иными словами, самые лучшие законы не заменят того, что традиционно ценилось во все времена: разум, честь, способности людей, находящихся на своих местах. Отсюда и совет Н.М. Карамзина подобрать пятьдесят толковых губернаторов («мужей умных, добросовестных»), ибо, по его мнению, «дела пойдут, как должно», когда будет наведен порядок на местах.

Сказанное по вполне конкретному поводу, в связи с образованием министерств («К чему писать законы, разве для потомства? Не бумаги, а люди правят» [3, с. 99-100]) приобретает у Н.М. Карамзина-консерватора характер принципиального понимания им значения законов в самодержавном государстве. Мудрый монарх всегда способен подобрать способных проводников своих замыслов, не подвергая каждого испытанию на соответствие букве закона.

Необходимо, на наш взгляд, отметить в контексте разговора о соотношении закона и традиции, что принципиальное различие между М.M. Сперанским и Н.М. Карамзиным в понимании ими феномена свободы определяло в немалой степени и различие между либеральной и консервативной (традиционной) моделями развития, которые они олицетворяли. На это обстоятельство указал в свое время В.А. Китаев: «Суть принципиальных расхождений между либерализмом и консерватизмом видится нам в выборе между внешней и внутренней свободой индивидуума, в признании или непризнании важности конституционно-правовых гарантий для ее осуществления в принципе. Выбор позднего Карамзина в пользу внутренней свободы, не нуждающейся в каком-либо правовом определении, - это выбор консерватора, и в этом качестве он противостоит либералу Сперанскому. Именно об этом свидетельствует карамзинская записка “О древней и новой России”» [6, с. 39]. 
Не принял Н.М. Карамзин идеи отмены крепостного права. Его позиция в этом вопроce, как, впрочем, и в остальных, - позиция консерватора: «...в государственном общежитии право естественное уступает гражданскому... благоразумный самодержец отменяет единственно те Уставы, которые делаются вредными или недостаточными и могут быть заменены лучшими» [3, с. 72]. Вредным Н.М. Карамзин считал не крепостное право, а его отмену, предрекая в этом случае ряд негативных последствий для казны, земледелия, социальных отношений, внутреннего политического спокойствия. Отсюда и безапелляционный вывод: «Не знаю, хорошо ли сделал Годунов, отняв у крестьян свободу (ибо тогдашние обстоятельства не совершенно известны), но знаю, что теперь им неудобно возвратить оную. Тогда они имели навык людей вольных ныне имеют навык рабов. Мне кажется, что для твердости бытия государственного безопаснее поработить людей, нежели дать им не вовремя свободу, для которой надобно готовить человека исправлением нравственным...» [3, c. 73-74].

Таким образом, модели реформированной России, с новыми государственными учреждениями, законами, социальными отношениями, модели, повторим, ориентированной на Европу, Н.М. Карамзин противопоставил классический консервативный подход - наше старое лучше того нового и чужого, что предлагают реформаторы: «Россия же существует около 1000 лет и не в образе дикой Орды, но в виде государства великого, а нам все твердят о новых образованиях, о новых уставах, как будто бы мы недавно вышли из темных лесов американских! Требуем более мудрости хранительной, нежели творческой» $[3$, c. 63$]$.

Результаты. Как видим, Н.М. Карамзин был решительно не согласен если не со всем, то со многим из того, что делалось в первые годы царствования Александра I, усмотрев в его деятельности продолжение начатой еще Петром Великим и унаследованной его преемниками политики вестернизации России. По справедливому замечанию А.Ю. Минакова, в этот период вестернизация воспринималась русскими консерваторами в качестве тотальной угрозы, разрушавшей все коренные устои русской жизни: самодержавие, церковь и веру, быт и национальные традиции, язык. И эта угроза была опаснее всех прежних исторических вызовов, включая монголо-татарское нашествие, так как раньше не подрывались принципы монархического правления, религия, не оспаривалась культурно-языковая идентификация [14, с. 7].

Зададимся вопросами: насколько реально в тех исторических условиях было в полной мере реализовать замыслы Александра I и проекты М.М. Сперанского, направить Россию по западному пути политического и социально-экономического развития? И еще: почему они не были реализованы? Сводилось ли все к известной формуле-фразе: «нет людей, не на кого опереться»?

Российское государство складывалось на основе великокняжеской вотчины: Великого княжества Московского. Также на основе дворцово-вотчинной системы формировались на рубеже XV-XVI вв. общерусские органы власти и управления. Идея государства-вотчины во многом определяла концепцию власти в целом в Русском государстве. Государьвотчинник Иван III, решая вопросы престолонаследия, заявлял, что волен по собственному усмотрению выбирать между внуком и сыновьями [15, с. 206]. Свое полное право распоряжаться жизнями и судьбами подданных утверждал в полемике с Андреем Курбским Иван IV [12, с. 26].

Такой концепции власти вполне соответствовала и форма правления Русского государства: она изначально складывалась как деспотическое самодержавие. А отношения между верховной властью и подданными формировались в форме подданства-министериалитета, то есть по типу «господин - слуга», что исключало возможность закрепления даже за господствующими сословиями какихлибо прав и привилегий, гарантий от произвола со стороны великого князя [7].

Деспотическому самодержавию, переходящему в абсолютизм, Петр I дал несколько иное идеологическое обоснование: необходимость служения государству, в одинаковой степени распространяющаяся на монарха и подданных; патернализм как форма отношений между верховной властью и подданными, при которой монарх - единственный, 


\section{ВЛАСТЬ И ОБЩЕСТВО}

кто точно знает, что нужно стране и народу, а дело последнего - исполнять все повеления самодержца как несущие безусловное благоденствие [1, с. 23, 62]. Но по существу это мало что меняло как в самом характере власти, так и в ее взаимоотношениях с подданными. Разве что насилию было дано более рациональное объяснение: оно применялось для достижения высших государственных целей [1, с. 60].

Фундамент российского либерализма закладывался в то время, когда для него не было политических и социально-экономических условий, в период господства самодержавия, эволюционирующего в абсолютную монархию. Поэтому на практике стремление Петра I поставить закон выше традиции служило идее создания регулярного полицейского государства - любимого детища царя-реформатора. (Под регулярным полицейским государством мы понимаем государство с предельной централизацией власти и ее постоянным и активным вмешательством не только в сферу политики, но и социально-экономические отношения, церковные дела, культуру, частную жизнь подданных.) Ситуация мало изменилась и к началу XIX века. Либеральная по своей сути идея разделения властей при определенных, благоприятных, условиях действительно могла привести к ограничению самодержавия и стать надежной основой конституционного устройства. В российских условиях реализация названной идеи вела лишь к рационализации системы управления.

Все это станет важными, среди прочих, факторами слабости русского либерализма, который так и не сумеет прочно утвердиться на русской почве, пустить здесь глубокие корни, стать мощной политической силой. Примером, с нашей точки зрения, может служить период между Февральской и Октябрьской революциями 1917 г., когда потерпела крах либеральная альтернатива. Да, накопленного к тому времени исторического потенциала русским либералам хватило для свержения самодержавия, но оказалось недостаточно, чтобы удержать власть.

Показательна дальнейшая судьба самого М.М. Сперанского. Из хорошо известных фактов обратим внимание лишь на один. Под его руководством были подготовлены Полное собрание законов Российской империи и Свод законов Российской империи. Правда, систематизация законодательства должна была не приблизить Россию к обретению политических и гражданских свобод, о чем некогда мечтал М.М. Сперанский, а содействовать реализации, как и при Петре I, идее регулярного полицейского государства, приверженцем которой был и Николай I.

Западная либеральная модель развития России, предложенная в начале XIX в. и могущая привести к конституционному устройству, на практике превратилась в преобразование государственного аппарата в рамках абсолютной монархии. Вековые исторические традиции, выразителем которых стал Н.М. Карамзин, оказались сильнее стремления императора Александра I дать России конституцию. Эти традиции сохраняли свою силу на протяжении всего XIX столетия. Может, и сейчас не стоит противиться собственной исторической судьбе? И если сегодня, после нескольких десятилетий социалистического эксперимента, либеральной «шоковой терапии» 1990-х гг., у консерватизма действительно появился шанс сыграть роль стабилизирующей и консолидирующей расколотое общество силы [9; 10], то было бы не лишним извлечь исторические уроки из неудачи наших либералов, прислушаться к некоторым, не потерявшим своей актуальности, размышлениям наших консерваторов.

Консерватизм многолик и вариативен. Как функция времени, консерватизм опирается на условия и состояния настоящего времени и, как правило, улавливает основные возможности в поиске управленческих новаций, направленных на достижение стабильности и консолидации общества и государства. Опираясь неизменно на социально-экономические, политические и культурно-правовые реальности, консерватизм способен находить и принимать приемлемые для настоящего ценности из конкурирующих мировоззренческих систем либерализма и умеренного социализма. Политическая практика европейских стран последних лет свидетельствует об этом. Однако конвергентность (в контексте к стремлению к позитивной стабильности в развитии общества и государства) не нарушает его фундаментальных основ. 


\section{СПИСОК ЛИТЕРАТУРЫ}

1. Анисимов, Е. В. Время петровских реформ / Е. В. Анисимов. - Л. : Лениздат, 1989. - 496 с.

2. Ведерников, В. В., Написана ли история русского либерализма? : (о книге В. В. Леонтовича) / В. В. Ведерников, В. А. Китаев // Общественная мысль и историческая наука в России XVIII-XX вв.: проблемы историографии / В. А. Китаев. - Нижний Новгород : Изд-во ННГУ, 2016. - С. 37-53.

3. Карамзин, Н. М. Записка о древней и новой России в ее политическом и гражданском отношениях / Н. М. Карамзин. - М. : Наука. Главная редакция восточной литературы, 1991. - 127 с.

4. Кизеветтер, А. А. Исторические очерки / А. А. Кизеветтер. - М. : ОКТО, 1912. - 502 с.

5. Китаев, В. А. У истоков русского консерватизма (М.М. Щербатов и Н.М. Карамзин) / В. А. Китаев // Материалы XI научной конференции профессорско-преподавательского состава, г. Волгоград, 18-22 апреля 1994 года. - Волгоград : Изд-во ВолГУ, 1994. - С. 131-137.

6. Китаев, В. А. ХІХ век: пути русской мысли / В. А. Китаев. - Нижний Новгород : Изд-во Нижегородского госуниверситета, 2008. - 355 с.

7. Кобрин, В. Б. Становление деспотического самодержавия в средневековой Руси (К постановке проблемы) / В. Б. Кобрин, А. Л. Юрганов // История СССР. - 1991. - № 4. - С. 54-64.

8. Леонтович, В. В. История либерализма в России, 1762-1914 / В. В. Леонтович. - М. : Российский путь : Полиграфресурсы, 1995. - 550 с.

9. Лотарев, К. А. Стабилизирующие и консолидирующие ресурсы консерватизма в России. Часть первая / К. А. Лотарев // Вестник Волгоградского государственного университета. Серия 4, История. Регионоведение. Международные отношения. - 2014. - № 6 (30). - C. 91-99. - DOI: https:// doi.org/10.15688/jvolsu4.2014.6.10.

10. Лотарев, К. А. Стабилизирующие и консолидирующие ресурсы консерватизма в России (Часть 2) / К. А. Лотарев // Вестник Волгоградского государственного университета. Серия 4, История. Регионоведение. Международные отношения. 2016. - T. 21, № 2. - C. 125-131.-DOI: https://doi.org/ 10.15688/jvolsu4.2016.2.12.

11. Мироненко, С. В. Самодержавие и реформы. Политическая борьба в России в начале XIX в.

/ С. В. Мироненко. - М. : Наука, 1989. - 240 с.

12. Переписка Ивана Грозного с Андреем Курбским. -М. : Наука, 1993. - 432 с.

13. План государственного преобразования графа М.М. Сперанского. (Введение к Уложению государственных законов 1809 г.) С приложением «Записки об устройстве судебных и правительственных учреждений в России» (1803 г.), статей
«О государственных установлениях», «О крепостных людях» и Пермского письма к Императору Александру. - М. : Издание «Русской мысли», 1905. -363 c.

14. Против течения: исторические портреты русских консерваторов первой трети ХІХ столетия / отв. ред. А. Ю. Минаков. - Воронеж : Воронежский государственный университет, 2005. - 417 с.

15. Скрынников, Р. Г. История Российская, IXXVII вв. / Р. Г. Скрынников. - М. : Весь Мир, 1997. $496 \mathrm{c}$.

16. Струве, П. Б. Исторический смысл русской революции и национальные задачи / П. Б. Струве // Из глубины : сборник статей о русской революции. М. : Изд-во Моск. ун-та, 1990. - С. 235-250.

17. Томсинов, В. А. Светило российской бюрократии: Исторический портрет М.М. Сперанского / В. А. Томсинов. - М. : Молодая гвардия, 1991.$336 \mathrm{c}$.

18. Чибиряев, С. А. Великий русский реформатор : Жизнь, деятельность, политические взгляды М.М. Сперанского / С. А. Чибиряев. - М. : Воскресенье, 1993. - 236 с.

\section{REFERENCES}

1. Anisimov E.V. Vremya petrovskikh reform [Time of Peter the Great's Reforms]. Leningrad, Lenizdat, 1989. 496 p.

2. Vedernikov V.V., Kitaev V.A. Napisana li istoriya russkogo liberalizma? (o knige V.V. Leontovicha) [Is the History of Russian Conservatism Written? (On the Book of V.V. Leontovich)]. Obshchestvennaya mysl $i$ istoricheskaya nauka v Rossii XVIII - XX vv.: problemy istoriografii [Social Thought and Historical Science in Russia in the $18^{\text {th }}-20^{\text {th }}$ Centuries: Problems of Historiography]. Nizhny Novgorod, Izd-vo NNGU, 2016, pp. 37-53.

3. Karamzin N.M. Zapiska o drevney i novoy Rossii $v$ ee politicheskom i grazhdanskom otnosheniyakh [A Note About Ancient and New Russia in Its Political and Civil Relations]. Moscow, Nauka. Glavnaya redaktsiya vostochnoy literatury Publ., 1991. 127 p.

4. Kizevetter A.A. Istoricheskie ocherki [Historical Essays]. Moscow, OKTO Publ., 1912.502 p.

5. Kitaev V.A. U istokov russkogo konservatizma (M.M. Shcherbatov i N.M. Karamzin) [At the Origins of Russian Conservatism (M.M. Shcherbatov and N.M. Karamzin)]. Materialy XI nauchnoy konferentsii professorsko-prepodavatelskogo sostava, g. Volgograd, 18-22 aprelya 1994 goda [Proceedings of the $11^{\text {th }}$ Scientific Conference of the Faculty, Volgograd, 18-22 April 1994]. Volgograd, Izd-vo VolGU, 1994, pp. 131-137. 
6. Kitaev V.A. XIX vek: puti russkoy mysli [The $19^{\text {th }}$ Century: Ways of Russian Thought]. Nizhny Novgorod, Izd-vo Nizhegorodskogo gosuniversiteta, 2008.355 p.

7. Kobrin V.B., Yurganov A.L. Stanovlenie despoticheskogo samoderzhaviya $\mathrm{v}$ srednevekovoy Rusi (K postanovke problemy) [Formation of a Despotic Autocracy in Medieval Russia (To the Problem)]. Istoriya SSSR, 1991, no. 4, pp. 54-64.

8. Leontovich V.V. Istoriya liberalizma $v$ Rossii, 1762-1914 [History of Liberalism in Russia, 17621914]. Moscow, Rossiyskiy put Publ., Poligrafresursy Publ., 1995. 550 p.

9. Lotarev K.A. Stabiliziruyushchie i konsolidiruyushchie resursy konservatizma v Rossii. Chast pervaya [Stabilizing and Consolidating Resources of Conservatism in Russia. Part 1]. Vestnik Volgogradskogo gosudarstvennogo universiteta. Seriya 4. Istoriya. Regionovedenie. Mezhdunarodnye otnosheniya [Science Journal of Volgograd State University. History. Area Studies. International Relations], 2014, no. 6 (30), pp. 91-99. DOI: https:// doi.org/10.15688/jvolsu4.2014.6.10.

10. Lotarev K.A. Stabiliziruyushchie i konsolidiruyushchie resursy konservatizma v Rossii. Chast 2 [Stabilizing and Consolidating Resources of Conservatism in Russia. Part 2]. Vestnik Volgogradskogo gosudarstvennogo universiteta. Seriya 4. Istoriya. Regionovedenie. Mezhdunarodnye otnosheniya [Science Journal of Volgograd State University. History. Area Studies. International Relations], 2016, vol. 21, no. 2, pp. 125-131. DOI: https://doi.org/ 10.15688/jvolsu4.2016.2.12.

11. Mironenko S.V. Samoderzhavie i reformy. Politicheskaya borba $v$ Rossii $v$ nachale XIX $v$. [Autocracy and Reform. Political Struggle in Russia in the Early $19^{\text {th }}$ c.]. Moscow, Nauka Publ., 1989. 240 p.

12. Perepiska Ivana Groznogo s Andreem Kurbskim [Correspondence of Ivan the Terrible with Andrei Kurbsky]. Moscow, Nauka Publ., 1993. 432 p.
13. Plan gosudarstvennogo preobrazovaniya grafa M.M. Speranskogo. (Vvedenie k Ulozheniyu gosudarstvennykh zakonov 1809 g.) S prilozheniem "Zapiski ob ustroystve sudebnykh i pravitelstvennykh uchrezhdeniy $v$ Rossii» (1803 g.). statey "O gosudarstvennykh ustanovleniyakh». «O krepostnykh lyudyakh» $i$ Permskogo pisma $k$ Imperatoru Aleksandru [The Plan of State Transformation of Count M.M. Speransky. (Introduction to the Code of State Laws of 1809) With the App "Notes on the Structure of Judicial and Governmental Institutions in Russia” (1803), Articles “On Public Institutions", “On Serf People" and Perm Letter to Emperor Alexander]. Moscow, Izdanie «Russkoy mysli», 1905. 363 p.

14. Minakov A.Yu., ed. Protiv techeniya: istoricheskie portrety russkikh konservatorov pervoy treti XIX stoletiya [Against the Current: Historical Portraits of Russian Conservators in the First Third of the $19^{\text {th }}$ Century]. Voronezh, Voronezhskiy gosudarstvennyy universitet, 2005. 417 p.

15. Skrynnikov R.G. Istoriya Rossiyskaya, IX$X V I I v v$. [The History Of Russia. $9^{\text {th }}-17^{\text {th }} \mathrm{c}$.]. Moscow, Ves Mir Publ., 1997. 496 p.

16. Struve P.B. Istoricheskiy smysl russkoy revolyutsii $i$ natsionalnye zadachi [The Historical Meaning of the Russian Revolution and National Problems]. Iz glubiny: sbornik statey o russkoy revolyutsii [From the Depths: Collection of Articles About the Russian Revolution]. Moscow, Izd-vo Moskovskogo universiteta, 1990, pp. 235-250.

17. Tomsinov V.A. Svetilo rossiyskoy byurokratii: Istoricheskiy portret M.M. Speranskogo [Luminary of the Russian Bureaucracy: Historical Portrait of M.M. Speransky]. Moscow, Molodaya gvardiya Publ., 1991. 336 p.

18. Chibiryaev S.A. Velikiy russkiy reformator. Zhizn, deyatelnost, politicheskie vzglyady M.M. Speranskogo [The Great Russian Reformer. Life, Work, Political Views of M.M. Speransky]. Moscow, Voskresenye Publ., 1993. 236 p.

\section{Information about the Authors}

Oleg V. Kuznetsov, Candidate of Sciences (History), Associate Professor, Head of the Department of Russian and World History, Archaeology, Volgograd State University, Prosp. Universitetsky, 100, 400062 Volgograd, Russian Federation, kusnezov_oleg@mail.ru, https://orcid.org/0000-0002-2075-6003

Konstantin A. Lotarev, Candidate of Sciences (Politics), Associate Professor, Department of International Relations, Political Science and Area Studies, Volgograd State University, Prosp. Universitetsky, 100, 400062 Volgograd, Russian Federation, lotarev16@mail.ru, https://orcid.org/0000-0002-9363-5608

Vasiliy V. Tarakanov, Doctor of Sciences (Economics), Professor, Rector, Volgograd State University, Prosp. Universitetsky, 100, 400062 Volgograd, Russian Federation, rector@volsu.ru, https://orcid.org/0000-0001-6971-0172 


\section{Информация об авторах}

Олег Викторович Кузнецов, кандидат исторических наук, доцент, заведующий кафедрой отечественной и всеобщей истории, археологии, Волгоградский государственный университет, просп. Университетский, 100, 400062 г. Волгоград, Российская Федерация, kusnezov_oleg@mail.ru, https://orcid.org/0000-0002-2075-6003

Константин Анатольевич Лотарев, кандидат политических наук, доцент кафедры международных отношений, политологии и регионоведения, Волгоградский государственный университет, просп. Университетский, 100, 400062 г. Волгоград, Российская Федерация, lotarev16@mail.ru, https://orcid.org/0000-0002-9363-5608

Василий Валерьевич Тараканов, доктор экономических наук, профессор, ректор, Волгоградский государственный университет, просп. Университетский, 100, 400062 г. Волгоград, Российская Федерация, rector@volsu.ru, https://orcid.org/0000-0001-6971-0172 